\title{
Maradi red goat sexual cycle: descriptive and progesteronomic study
}

\author{
Karimou HAROUNA BOUREIMA ${ }^{1 *}$, Adoulkarim ISSA IBRAHIM ${ }^{1}$, Mamman MANI $^{2}$ \\ and H. ARICHATOU ${ }^{3}$ \\ ${ }^{1}$ Université Boubakar BA de Tillabéri, BP 175, Niger. \\ ${ }^{2}$ Institut National Recherche Agronomique du Niger, BP 429 Niamey, Niger. \\ ${ }^{3}$ Université Abdou Moumouni, Niamey, BP 10662, Niger. \\ ${ }^{*}$ Corresponding author; E-mail: kahboureima@yahoo.com, Tél: (00227)96494021, Fax: 0022720316612
}

\begin{tabular}{lll}
\hline Received: 09-06-2020 & Accepted: 22-01-2021 & Published: 28-02-2021 \\
\hline
\end{tabular}

\begin{abstract}
In order to establish the cyclicity characteristics of the Maradi red goat for the selection program, two experimental protocols were implemented separately at the Faculty of Agronomy of the University of Niamey (Niger). The first included 8 multiparous females and aimed to characterize the plasma progesterone concentration during the sexual cycle. The second including 31 females (multiparous and young) focused on analyzing manifestation of sexual activity and determining averages durations of estrus and sexual cycle. Blood samplings and heat controls were conducted. It appeared that young female puberty occurs at 46 to $56 \%$ of adult goat weight and the onset and end of heats are widely detected in the morning (65\%). Throughout the year, sexual activity is lower in dry and hot season and higher in rainy and dry and cold season. The averages lengths of estrus and sexual cycle are $43.27 \pm 26.54$ hours and $23.16 \pm 16.68$ days. These parameters vary, $(\mathrm{p}=5 \%)$ between type of females for the length of sexual cycle with a high proportion of abnormal cycles $(31.61 \%$ short and $28.57 \%$ long). progesterone profiles showed the same trend. Concentration is lower at estrus period $(0.29 \pm 0.12 \mathrm{ng} / \mathrm{ml})$, it rises from the $4^{\text {th }}$ day to reach a peak of $6 \pm 1.6 \mathrm{ng} / \mathrm{ml}$ between the $13^{\text {th }}$ and $16^{\text {th }}$ day of the cycle.
\end{abstract}

(C) 2021 International Formulae Group. All rights reserved.

Keywords: Durations, Cycle, Estrus, Progesterone, Evolution, Maradi Red goats.

\section{INTRODUCTION}

In Niger, the red goat of Maradi represents $17 \%$ of all breeds of goats (Rhissa 2010). It is an emblematic farm animal in the southern belt of the country near the border with Nigeria. It enjoys a special status in the livestock sector of Niger. For several decades, it attracted the interest of animal scientists, tanners, dealers in leather goods, as well as development partners because of the exceptional value of its skin (thin, flexible and remarkably strong) and its important prolificacy (high frequency of twins and triplets). Because of all these qualities, soon after independence, the Niger government established in 1962, the Maradi Goat Breeding Center in view of selecting for this breed on the basis of pelage. Many documents refer to this breed, especially its ethnological map (Marichatou et al., 2012), its reproductive parameters (Marichatou et al., 2002; Saadou, 2005), and the socio-economic aspects regarding its production performance (Saadou, 
2009). However, reproduction studies were more confined to parameters of the reproductive career. These studies being conducted in real environment, they could not address estrus characteristics, sexual cycle and other sexual physiology parameters in the cycles of both sexes since these are difficult to assess in that environment. The main objective of the present study was to fill this gap by establishing the sexual activity characteristics of this race.

\section{MATERIALS AND METHODS Study sites and periods}

The work was conducted in the experimental station of the Faculty of Agronomy (University of Niamey). This park is at an altitude of $216 \mathrm{~m}$ and located at the $18^{\circ} 30$ 'north latitude and $2^{\circ} 08^{\prime}$ east longitude coordinates. The activities took place in two phases: the first from September to December 2015 aimed at characterizing the evolution of: plasma progesterone concentration during the reproductive cycle and the second, from January to December 2016 focused on analyzing the manifestation of sexual activity and determining the duration of estrus and sexual cycle.

\section{Animal material and conduct}

For plasma concentration evolution, eight multiparous goats (average weight $21.31 \pm 3.13 \mathrm{~kg}$ ) were used and for the cyclicity study, some 31 females (16 multiparous and 15 young female goats) were used.

All the animals were identified with plastic ear loops and kept in loose housing in parks with ad libitum watering. Feed rations consist of Zornia glochidiata or Echinocloa stagnina, wheat bran and salt licks (mineral salts and trace elements).

\section{Experimental protocol Heat Control}

Heat detections were conducted through two daily exposures (8 AM and 5 PM) of both females to bucks harnessed with non-marker protective aprons and trained for this purpose from early experiments. Five bucks were used for each control (about ten minutes for each one) because some females in heat are often capricious, refusing one male and accepting another. The stillness and acceptance of females to be overlap by male were be considered as signs of early heat. The dates and times for the start and end of heat were regularly recorded for each female goat.

\section{Blood sampling}

Blood samples were obtained by venipuncture at the jugular vein, using sterile tubes Vacutainer (EDTA). They were conducted daily right at the onset of heats during estrus and three times a week (Monday, Wednesday and Friday) until the appearance of new heats and this over several cycles.

After sampling, tubes were placed in coolers and immediately taken to laboratory where the blood is centrifuged at $4000 \mathrm{rpm}$ at $4{ }^{\circ} \mathrm{C}$ for $10 \mathrm{~min}$. The plasma is collected in Eppendorf tubes and kept frozen until assayed.

\section{Dosage of progesterone}

The dosage was performed according to the "Radio Immuno Assay (RIA)" method. The principle is based on a competition between a labeled antigen said to be hot $(\mathrm{Ag} *)$ and a cold or unlabelled antigen $\left(\mathrm{Ag}^{\circ}\right)$ contained in the plasma, with respect to a limited number of antibody sites.

To this end, a (SAS IMMUNOTECH, Marseille Cedex 9, France) commercial kit was ordered and used. Analyses were conducted at the Laboratory of the Department of Nuclear Medicine at the Radio Isotopes Institute (IRI) of University of Niamey. The material used includes three components: blood plasma samples for analysis, reagents (kit) and laboratory equipment.

\section{Data analysis}

\section{Calculation of cyclicity parameters}

To calculate the desired cyclicity parameters (cycle length, estrus duration) using heat control data, the following 
definitions proposed by Mani (2009) were considered:

- The onset of estrus is considered to be at half the interval of time between the first observation of heats and the preceding one; - The end of estrus is defined to occur at half the time interval between the last observation of heat and the first observationof non-accepted overlap; - The duration of sexual cycle is considered to be the time between two consecutives early manifestations of heat.

In addition, the categorization of cycles into normal (17-25 days), short ( $<17$ days) and long cycles ( $>25$ days) described by Mani (2009) was used for the data analysis of cyclicity.

\section{Statistical analysis}

All heat control data were entered and treated in a model established for this purpose in the SPSS 17.0 software. This treatment consisted of a descriptive analysis and a comparison of means (ANOVA). However, summaries of control heat and progesterone dosage data processed as tables and figures were done using Excel spreadsheet.

\section{RESULTS}

\section{Characteristics of sexual activity Puberty}

Nine of the fifteen young female goats showed signs of heat. They all had a pair of permanent incisors and therefore could be considered to be aged 1-2 years. Their weights at the first sign of heat are shown in Table 1.

This table shows that the weight of young female goats at puberty varies from 10.6 to $15 \mathrm{~kg}$ with an average weight of $12.94 \pm 1.42$ corresponding to the range of $46.21 \%$ to $56.26 \%$ of the weight of adult females $(23-28 \mathrm{~kg})$.

\section{Nychthemeral event of sexual activity}

Figure 1 presents the beginning and end of heats at different times of the day (morning and evening). This figure shows that for red goat of Maradi, the beginning and end of heat events are observed in the morning as well as in the evening. However, it should be noted that most of these occurred in the morning (67\% against 33\% in the evening). The end of heats is also distributed in the same frequency: 69\% in the morning against $31 \%$ in the evening.

\section{Duration of estrus and sexual cycle Duration of estrus}

The average duration of estrus of the Maradi red goat obtained from all observations was $38 \pm 43.27$ hours (Table $2)$. There are large variations between individuals ranging from 24 to 240 hours. However, the analysis of variance showed that the difference was not statistically significant $(\mathrm{p}=0.319)$ between adult and young female goats.

\section{Duration of sexual cycle}

As the duration of estrus, the sexual cycle also experiences individual variations between invidious (Table 3). Hence, the same female goat can in the course of its sexual activity go through the three types of cycles (short, regular or long). Proportions obtained for all observations are $40.18 \%$, $31.61 \%$ and $28.57 \%$ respectively of normal, short and long cycles. The overall average obtained is $23.16 \pm 16.68$ days, but the analysis of variance showed that cycles are statistically longer among young female goats than adults $(\mathrm{p}=0.008)$.

\section{Variation of sexual activity throughout the year}

It emerged from the observations that the sexual activity of the female red goat of Maradi varies throughout the year. Figure 2 differentiates two phases: a phase of low sexual activity from February to June and a phase of higher sexual activity with peaks in the months of July and August.

\section{Evolution of progesterone concentration during the reproductive cycle}

A total of 140 plasma samples were used for dosage of progesterone; they relate to empty goats observed at least twice in heat events and with normal cycles. Figure 3 shows plot moving average trends in the 
evolution of the plasma progesterone levels for 7 cycles.

\section{Average trends}

This figure shows that the level of progesterone during normal cycles evolve according to the same trend. However, progesterone concentration varies from one cycle to the other according to the different phases. It is low at estrus phase, a mean of $0.29 \pm 0.12 \mathrm{ng} / \mathrm{ml}$, ranging between 0.08 and $0.6 \mathrm{ng} / \mathrm{ml}$ for 2 to 3 days. It starts rising from the fourth day to reach a maximal mean of $6 \pm 1.6 \mathrm{ng} / \mathrm{ml}$ (range of 4 to $10 \mathrm{ng} / \mathrm{ml}$ ) between the $13^{\text {th }}$ and the $16^{\text {th }}$ days of the cycle. From the $17^{\text {th }}$ day, the level of progesterone falls at once and leads to the apparition of estrus.

Table 1: Weight of young female goats at the first sign of heat.

\begin{tabular}{lcccccccccc}
\hline Animals number & $\mathbf{5 6}$ & $\mathbf{5 9}$ & $\mathbf{6 6}$ & $\mathbf{6 8}$ & $\mathbf{7 0}$ & $\mathbf{7 5}$ & $\mathbf{7 6}$ & $\mathbf{7 8}$ & $\mathbf{8 5}$ & Average \\
& & & & & & & & & & \\
\hline Weight & 11,4 & 14 & 15 & 14,1 & 13,4 & 12 & 12,5 & 13,5 & 10,6 & $12,94 \pm 1,42$ \\
& & & & & & & & & & \\
\hline
\end{tabular}

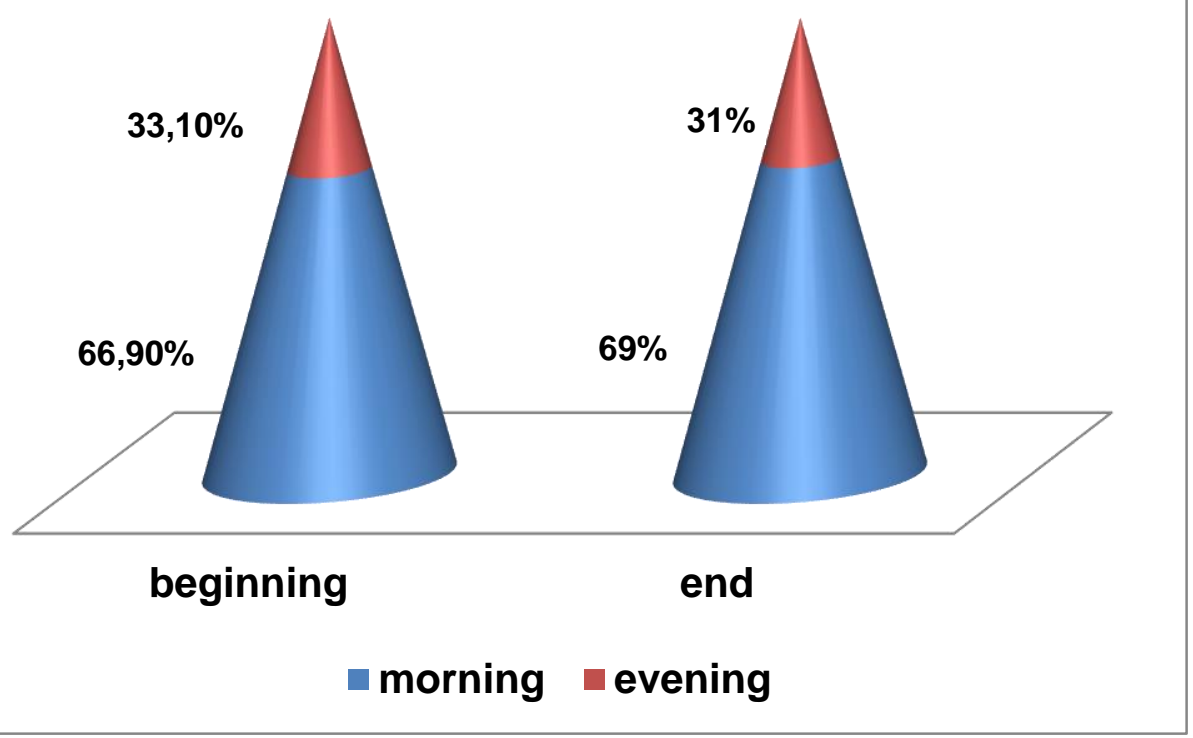

Figure 1: Diurnal distribution of beginning and end of heats in the red goat of Maradi.

Table 2: Means, standard deviations (SD) and extreme values of the duration of estrus.

\begin{tabular}{llllll}
\hline Categories females & N & Mean & SD & Minimum & Maximum \\
\hline Adult goat & 115 & $44,348^{(\mathrm{a})}$ & 28,7936 & 24,0 & 240,0 \\
Young & 27 & $38,667(\mathrm{a})$ & 12,6004 & 24,0 & 72,0 \\
All Categories & 142 & 43,268 & 26,5442 & 24,0 & 240,0 \\
\hline
\end{tabular}


Table 3: Mean duration of the sexual cycle of the red goat of Maradi by female category.

\begin{tabular}{|c|c|c|c|c|c|c|c|c|}
\hline \multirow{2}{*}{ Goat } & \multicolumn{2}{|c|}{ Short Cycle } & \multicolumn{2}{|c|}{ Regular Cycle } & \multicolumn{2}{|c|}{ Long Cycle } & \multicolumn{2}{|c|}{ All kind of cycle } \\
\hline & $\overline{\mathrm{N}}$ & Duration & $\overline{\mathrm{N}}$ & Duration & $\overline{\mathrm{N}}$ & Duration & $\bar{N}$ & Duration \\
\hline Adult Goat & 33 & $7,4 \pm 3,81$ & 35 & $22,50 \pm 1,4$ & 26 & $37,64 \pm 12,78$ & 94 & $21,38 \pm 13,9^{\text {(a) }}$ \\
\hline Young & 2 & $5,75 \pm 0,35$ & 10 & $20,95 \pm 1,52$ & 6 & $60,50 \pm 26,63$ & 18 & $32,44 \pm 25,48^{(b)}$ \\
\hline All Categories & 35 & $7,3 \pm 3,72$ & 45 & $22,16 \pm 1,54$ & 32 & $41,92 \pm 18,12$ & 112 & $23,16 \pm 16,68$ \\
\hline
\end{tabular}

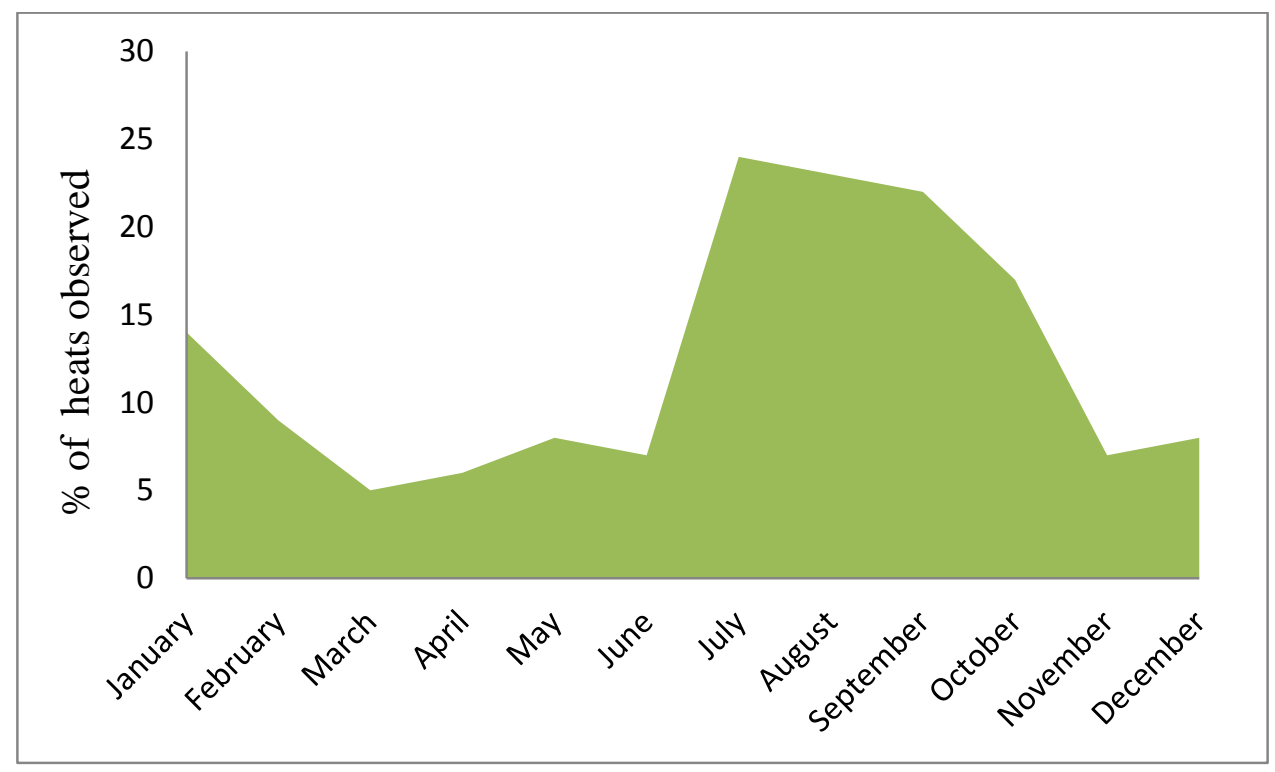

Figure 2: Variation of heat frequency in the different months of the year.

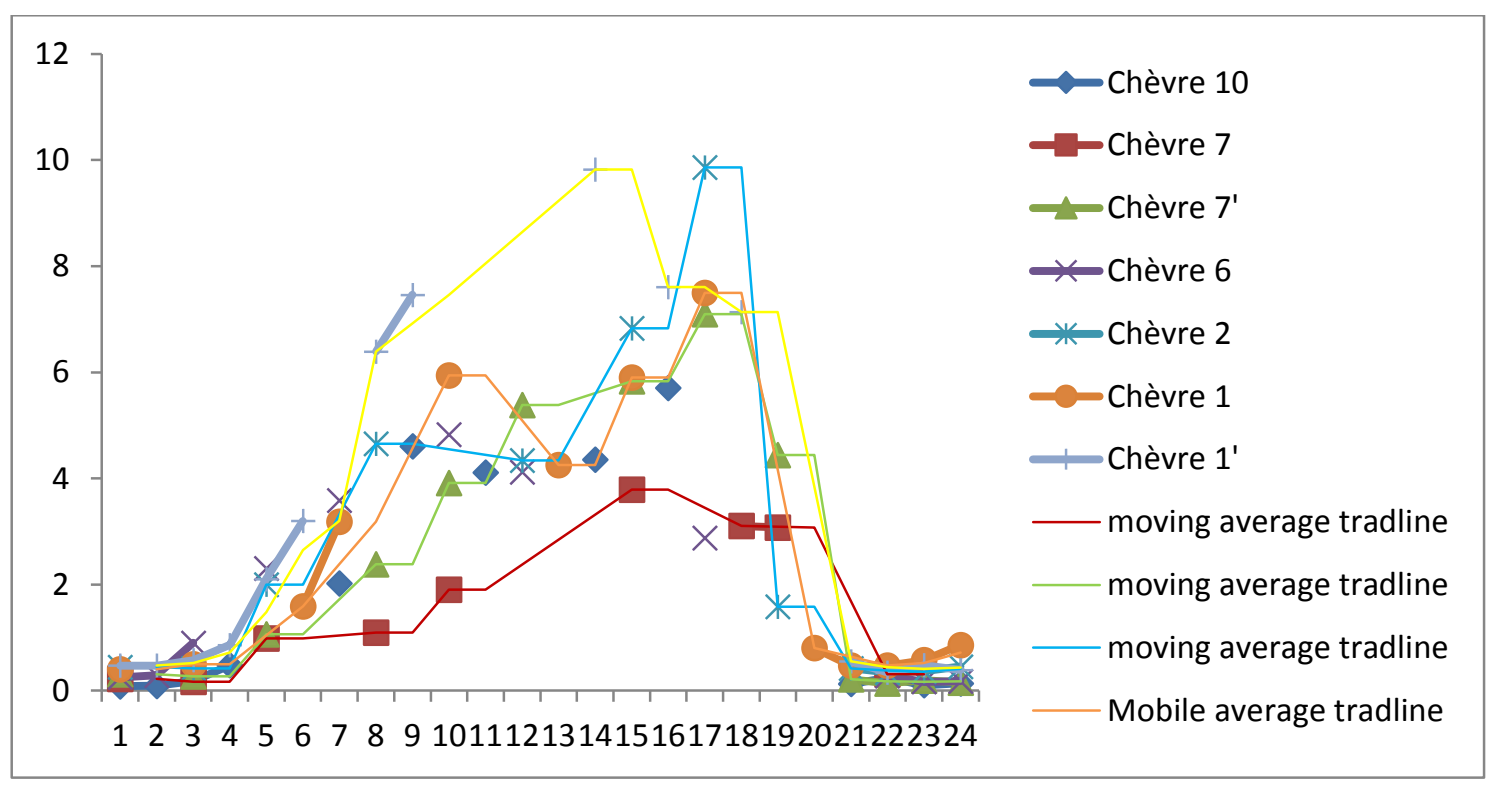

Figure 3: Evolution of plasma progesterone for 7 normal cycles. 


\section{DISCUSSION}

The heat detection method used (goats harnessed with protective aprons and an observer to record overlaps) is a classic method as reported by Fabre-Nys (2000). For Vaillancourt and Lefebvre (2003), even though the goat estrus is more demonstrative, its detection remains difficult and less accurate in the absence of males. Using several bucks in rotation for the control aimed at minimizing the effect of the capricious behavior some females may show by refusing one male goat and accepting the other (Fabre-Nys, 2000).

Puberty can be considered as the age of appearance of the first signs of heat followed by the usual activities of the ovarian cycle (Greyling, 2000). It depends on several factors including race, time of birth of the kid, production system, genetics (Freitas et al., 2004; Audrey, 2012). In this study, all the young goats experiencing heat for the first time had a pair of permanent incisors thus considered to be aged 1 to 2 years. However, this age is not sufficiently critical because births are not grouped and do not take place in the same season. According to Freitas et al. (2004), puberty in less seasonal races depends more on weight than age. The average weight of young goats at the first signs of heat is 12.94 $\mathrm{kg}$ ranging individually from 10.6 to $15 \mathrm{~kg}$. Considering the weight of an adult female in the Maradi red goat as reported by Mani (2009), to be between 23 to $28 \mathrm{~kg}$, one can deduce that the average weight at puberty in female red Maradi varies from $4621 \%$ to $56.26 \%$ of the weight at adult age. This range of weight is consistent with that reported by Zarruq and al. (2001), Freitas and al. (2004), Audrey (2012) which is respectively $45-55 \%$, $45-50 \%$ and $40-60 \%$ of adult weight.

It appeared that the beginning and end of heats are detected especially in the morning (over 65\% each). Zarrouk et al. (2001) report that in goats, estrus is spotted mostly in the morning $(35 \%)$ and $25 \%$ at night. Taking into account the definitions of onset and end of heats by Mani (2009), as mentioned above, it can be deduced that heats start and end for most cases around midnight.

Throughout the year, it is observed that sexual activity goes through two phases: a low phase from February to June corresponding to the hot and dry season when the temperature is the highest (March, April, May) and a phase of high sexual activity from July to January corresponding to the rainy season (JulyOctober) and the dry and cold season (November-January). However, it is reported that in the tropical zone, females do not exhibit marked seasonality (Zarruq et al., 2001; Saadou 2005; Pamo et al., 2007). This trend is in line with the data reported by which indicate that under tropical conditions, in the equatorial zone where there are little variations between day and night lengths, local goat breeds can produce all year round and demonstrate low seasonality with loss of fertility. The influence of the climate characterized by variations in temperature from one month to the other can justify the reduction in sexual activity because photoperiod which influences the onset of estrus is low in the Tropics. Among other climate elements, high temperatures can also account for his situation as reported by Zarruq et al. (2001) who observed that high temperatures can reduce sexual activity for a few months. It resumes with the onset of rainy season. The analysis of changing climatic parameters in Niamey (Weather on line, 2013) showed that the observed period of low sexual activity is characterized by high temperatures and large thermal amplitudes. The high sexual activity phase begins with the onset of rains, evolves in line with the amount of rains and continues in the dry and cold season.

The average duration of estrus obtained from the red goat of Maradi is close to the average reported by Harouna (2014), Vaillancourt and Lefebvre (2003), which is 40 hours but typically higher than the average of the Mossi goat (Tamboura and al., 1998), which is $20 \pm 2$ hours and slightly above that of the Boer Goat (Greyling, 2000), which is 37.4 \pm 8.6 hours. The range of variation observed in nulliparous females is consistent with that reported by Zarruq et al. (2001). However, with multiparous females, long durations of estrus were obtained due to a female that could accept male overlapping for ten days. For this case, an observation of the ovarian activity is required to assess if this estrus is followed or not by ovulation. 
The average duration of sexual cycle in multiparous goats is consistent with the data reported in the scientific literature, i.e. 21 days (Zarruq, 2000; Greyling, 2000; Zarruq et al., 2001; Audrey, 2012). However, the average length observed in nulliparous female (32.44 \pm 25.48) was significantly higher than this standard duration. This may be inherent to the persistence of silent heats (ovulation without estrus behavior) in these nulliparous females. Considering the two categories of females, results show the importance of abnormal short and long cycles. Compared to the observation of Lassoued and Rekik (2005) about short cycles at the onset and end of the season, these abnormal cycles are observed in a disordered manner with the red goat of Maradi. This may be due to the male effect or the proximity to other females in estrus reported by Fabre-Nys (2000) and Gahery (2012).

Progesterone profiles during normal sexual cycles have the same trend as that of other breeds of goats as reported by Harouna (2014) Differences (level and range of the peak) is only the result of variations between races. Between species, the profiles of the plasma progesterone obtained are consistent with that of the serum progesterone in Boujaâd Morocco sheep (INRA Morocco, 2009). The average concentration of progesterone during estrus $0.29 \pm 0.12 \mathrm{ng} / \mathrm{ml}$ (range 0.08 to $0.6 \mathrm{ng} /$ $\mathrm{ml}$ ) is in line with that obtained by Sousa et al. (2004), Greyling (2000) on the Boer goat and INRA Morocco (2009) on the Boujaâd sheep. But this average is less than the one reported by Selvaraju et al. (2007) on the Malabari goat. The peak of progesterone $6 \pm 1.6 \mathrm{ng} / \mathrm{ml}$ (ranging from 4 to $10 \mathrm{ng} / \mathrm{ml}$ ) observed between the 13th and the 15th or 16th day of the cycle is within the range given by NysFabre (2000) and in line with the one reported by Sousa and al. (2004), but higher than that obtained by Greyling (2000).

\section{Conclusion}

The study shows that the red goat of Maradi shares some common characteristics with other goat breeds in general with regard to the weight at puberty, the diurnal distribution of estrus, individual variations in the length of estrus and sexual cycle as well as the evolution of progesterone concentration in the reproductive cycle. However, variations in the duration of estrus and sexual cycle were observed compared to other breeds. These changes can only be typical to the breed since a variety of results are reported for different races. In addition, this study found that the red goat of Maradi experiences a phase of low sexual activity in the hot, and dry season, when there are high temperatures and high thermal variations. Definitely, the study may lay some foundations for the genetic improvement of the red goat of Maradi. However, a further study on ovarian activity is required to assess if estrus is followed by ovulation, on the one hand and to better discuss the observed variation in sexual activity during the year, on the other hand.

\section{COMPETING INTERESTS}

The authors of this paper declare they have no competing interest for this work.

\section{AUTHORS' CONTRIBUTIONS}

KHB managed the animals, collected the data and entered them into the analysis software; AII prepared the bibliographic research manuscript; MM developed the data entry mask and took care of the statistical analysis; HM oversaw the research, support, advice and synthesis of the results.

\section{ACKNOWLEDGEMENTS}

The authors express their thanks to the agents of Maradi red goat center.

\section{REFERENCES}

Audrey C. 2012. La physiologie de la reproduction caprine. Institut de l'élevage.Paris.from.http:

//www.capgenes.com /IMG/pdf_2012_Fiche_GRC_PHYSIOL OGIE.pdf (Retrieved September 13, 2014).

Baril G, Chemineau P, Cognie Y, Guérin Y, Leboeuf B, Orgeur P, Vallet JC. 1993. Manuel de formation pour l'insémination artificielle chez les ovins et les caprins. Rome: FAO. (Production et Santé Animale). 
Harouna S. 2014. Caractéristiques du cycle œstral de deux races caprines du Niger: la chèvre du sahel et la chèvre rousse de Maradi. Thèse de Doctorat. Ecole inter des Sciences et Médecine de Dakar.

Institut National de Recherche Agronomique du Maroc. 2009. Activity Report on Animal Production: Des résultats probants pour le développement de l'élevage des petits ruminants. ADDENSUM Production Animale.

Lassoued N, Rekik M. 2005. Variations saisonnières de l'œstrus et de l'ovulation chez la chèvre locale Maure en Tunisie. Revue Élev. Méd. vét. Pays trop., 58 (1-2) : 69-73.

Marichatou H, Karimou B, Issa M, Chaibou M, Banoin M, Yénikoye A, Falke DI, Ayatunde A. 2012. Caractérisation morphologique de la chèvre rousse du Niger. Animal Genetic Resources, 51: 89-97.

DOI: 10.1017/S2078633612000458.

Marichatou H, Mamane L, Banoin M, Baril G. 2002. Performances zootechniques des caprins au Niger : étude comparative de la chèvre rousse de Maradi et de la chèvre à robe noire dans la zone de Maradi. Rev. Elev. Méd. Vét. Pays Trop, 55 (1) : 79-84.

Mani M. 2009. Le cycle sexuel de la chèvre rousse de Maradi : Etude descriptive et progestéronomie. Mémoire : Productions Animales et Développement Durable : Dakar (EISMV) ; 5 .

Pamo ET, Boukila B, Tendonkeng F. 2007. Goat production research in Africa: a sign post review for research in the new millennium. Int. J. Biol. Chem. Sci., 1(1): 76-89. DOI: 10.4314/ijbcs.v1i1.39702.

Rhissa Z. 2010. Revue du secteur de l'élevage au Niger. Niger: Ministère de l'Elevage, des Pêches et des Industries Animales.
Saadou M. 2005. Performance de reproduction et de production de la chèvre rousse de Maradi en milieu rural au Niger. Med. Vet Thesis Dakar: EISMV Dakar.

Saadou M. 2009. Impact de l'élevage de la chèvre rousse de Maradi sur le statut socio-économique de la femme rurale au Niger. Master thesis, Productions Animales et développement Durable: EISMV Dakar.

Selvaraju M, Kathiresan D, Devanathan TG. 2007. Serum progesterone profile during oestrus and early pregnancy in malabari goats. Tamilnadu J. Veterinary \& Animal Sciences, 3(1): 47-48. DOI: 10.1080/00288233.2001.9513473.

Sousa N.M, Gonzalez F, Karen A, EL Amiri B, Sulon J, Baril G, Cognie Y, Szenci O, Beckers JF. 2004. Diagnostic et suivi de gestation chez la chèvre et la brebis. Renc. Rech. Ruminants, 11 : 377-380.

Vaillancourt D, Lefebvre R. 2003. La gestion de la reproduction chez les petits ruminants : Le contrôle du cycle œstral. Le Médecin Vétérinaire du Québec, 33 (1 et 2) : 43-49.

Weather Online. 2013. Aéroport international Diori Hamani (227m). From http://www.wofrance.fr/weather/maps/cit y. (Retrieved january 10, 2013).

Zarrouk A. 2000. Les protéines associées à la gestation: reflet d'une insuffisance placentaire au cours de gravidités défaillantes chez la chèvre. Veterinary Sciences $\mathrm{PhD}$ Thesis, Liège: University of Liège.

Zarrouk A, Souilem O, Drion P.V, Beckers JF. 2001. Caractéristiques de la reproduction de l'espèce caprine. Ann. Méd. Vét., 145: 98-105. 